\title{
Cannes 2003 Report
}

\author{
By Ron Holloway \\ Fall 2003 Issue of KINEMA
}

\section{INTRODUCTION}

Cannes, like Paris for Hemingway, is a moveable feast. So if the Competition appears somewhat lacking, as it did this year, you spend more time viewing entries in Un Certain Regard. Or you pay a couple more visits to the Quinzaine des Réalisateurs. Or you check out entries at the Semaine Internationale de la Critique. Or you cue up at the Federico Fellini Retrospective to see Claudia Cardinale introduce 8 1/2 (Italy, 1963). Or you marvel at Oliver Stone's adroit command of French at his Le Leçon de cinéma, the festival's annual "film master class." Or you relive a moment of Cannes history at a Soirée in memory of the late French producer Daniel Toscan du Plantier in the Salle Debussy, where a large French film delegation turned up for a special screening of Maurice Pialat's Sous le Soleil de Satan, the 1987 Palme d'Or winner produced by Toscan du Plantier. That moment of nostalgia counted, for I remember all too well that cacophony of boos and cheers that greeted Pialat when he walked onstage to defiantly hold his palm in the air for all to see.

For many, the flight from a rather mediocre competition led to the Salle Buñuel under the roof of the Palais des Festivals to relish the visual delights of "Restored Films, Rescued Films" in a new festival section. A windfall for the cineaste, the series embraced a cross-section of genres, styles, periods, and cinematographies. Topping the list were: Luis Buñuel's Un Chien Andalou (France, 1929), Jean Renoir's Les Marseillaise (France, 1938), Michael Curtiz's Mildred Pierce (USA, 1945), the director's cut of Alberto Lattuada's I dolci inganni (The Adolescents, Italy, 1960), Pier Paolo Pasolini's Il Vangelo secondo Matteo (Italy, 1964), and Richard Brooks's In Cold Blood (USA, 1967). I spent an evening with my youth at the screening of a stunning black-and-white print of In Cold Blood, adapted from Truman Capote's best-seller with the versatile Scott Wilson in his first major screen role.

\section{THE COMPETITION}

\section{Columbine Revisited: Gus van Sant's Elephant}

Gus van Sant's Elephant (USA) was the surprise winner of this year's Golden Palm. The HBO telefeature, remarkable mostly for its cast of non-professional high-school teenagers, might not have gotten this far in the Cannes annals had it not been for Michael Moore's Bowling for Columbine, the documentary hit at the previous festival. Again, we are back in a suburban high school on an idyllic autumn day. Van Sant's digital camera picks up details, sometimes repeating scenes from different angles and perspectives. We pass boys in a game of touch football, overhear girls in a corridor exchanging back-biting barbs, wander in and out of classrooms, pay visits to the cafeteria and library. It's a day like any other at Watt High, a sprawling high school complex in Suburbia, USA - save that this one is about to explode when a couple of callow youths return home to open their mail-order delivery of guns and ammunition, don military combat uniforms, and return for their rendezvous with destiny on the school battlefield.

Regardless of whether Elephant will be graced with a cinematic release in the United States (the decision apparently lies with HBO), the film was doubly honoured at Cannes with awards for Best Film and Best Director, a jury decision that effectively closed the gap between film and maker. Two more double-awards were to follow, which also says something about this year's International Jury at Cannes, headed by President Patrice Chéreau.

\section{Potholes at Grover's Corners: Lars von Trier's Dogville}

Lars von Trier's Dogville (Denmark-Sweden-France-Germany-UK), a costly digitally shot entry running at three hours, came away empty-handed at Cannes - although, throughout the festival, it was the day-to-day favourite of voting critics. Fascinating only as a cinematic experiment, Dogville bears an uncanny, turnedinside-out resemblance to Thornton Wilder's Our Town, his 1938 stage classic set in Grover's Corners, New Hampshire - or "In the Mind of God," as Wilder referred to this rural community. Filmed entirely inside an abandoned Swedish machine factory, with the streets and buildings painted on a black-lacquered floor to point directions and help trigger your imagination, Dogville shows the seamy side of small-town morality, 
the hidden evil lurking beneath the surface of this isolated Godville community in the Rockies.

But once you get to the point midway through the film - when Grace (Nicole Kidman), the mysterious lady in a worn evening gown on the run from gangsters, gets raped by Chuck (Stellan Skarsgard), the grubby farmer, and Thomas Edison Jr. (Paul Bettany), the young idealist, does nothing about it - the last hour is suffocating. Grace, enchained as the town slave and prostitute, awaits her liberation by the gangster don (James Caan), then hardly blink an eye as she takes her revenge in a bloodbath. Is Dogville a brazen attack on Godville, the American Way of Life? Hardly - Gus van Sant's Elephant kicked harder. An acting tour-de-force? The talents of Lauren Bacall and Ben Gazzara, and many others, are wasted on banal and colourless dialogue. An aesthetic dogma statement? Say what you will about von Trier's hand-held digital-shooting principles, a wobbling camera is still a wobbling camera.

\section{French Eroticism: François Ozon's The Swimming Pool}

"I don't know if he likes women," said Catherine Deneuve about François Ozon, "but he does like actresses." Evidently two of his favourites are Ludivine Sagnier and Charlotte Rampling. Sagnier appeared in Gouttes d'eau sur pierres brûlants (Water Drops on Burning Rocks, 1999), a screen adaptation of Rainer Werner Fassbinder's claustrophobic melodrama, and 8 Femmes ( 8 Women, 2001), a whodunit conceived loosely along the lines of George Cukor's The Women (USA, 1939). Rampling played the imperturbable English lecturer in Sous le sable (Under the Sand, 2000), a stylish psychodrama of a deranged woman in communion with her dead husband. The mystery drama prompted some critics to peg François Ozon as the second François Truffaut. Now Sagnier and Rampling appear together for the first time in The Swimming Pool, the most alluring of the nine films by French directors in the Sélection Officielle at Cannes.

Charlotte Rampling picks up where she left off in Under the Sand. This time, in a similar tale of repressed eroticism, she's Sarah Morton, an icy British mystery writer who has lost her creative writing touch. When her publisher sends her to his villa in the Provence for a rest, he doesn't inform her that she might be visited by his French daughter, Julie (Ludivine Sagnier), whose loose morals and overheated sexual drives are enough to upset any writer's retreat. At first repulsed, then fascinated by her guest, Sarah begins to spy on Julie as she lies languidly next to the swimming pool during the day after a nightly sexual bout. And her writing skills are gradually rekindled when she reads pages from Julie's secret diary. The twist comes when Sarah and Julie find themselves with a murder caper on their hands - enough material in the end to assure the publication of another crime best-seller by the rejuvenated Sarah Morton. The Swimming Pool is François Ozon's best film to date.

\section{Time Trilogy: Nuri Bilge Ceylan's Uzak}

The best film of the festival? It came from Turkey: Nuri Bilge Ceylan's Uzak (Distant). Arriving in Cannes a month after the Istanbul film festival, where it had received three major awards: Best Turkish Film, Best Turkish Director, and International Critics (FIPRESCI) Prize. Distant, another doublewinner at Cannes, was awarded the runner-up Grand Jury Prize. Also, Muzaffer Özdemir and Mehmet Emin Toprak were jointly awarded the Best Actor Prize - for which jury president Patrice Chéreau had to request special festival permission in view of the fact that Toprak had recently died in a tragic car accident.

Distant is the third film in a Ceylan trilogy about the natural passage of time within predetermined space, about the solitude of the country giving way to loneliness of the city, about traditional family values bartered at a price for urban modernity. The unemployed young man (Mehmet Emin Toprak) from a village who pays his photographer cousin (Muzaffer Özdemir) a visit in Istanbul, in hopes of finding a job on a ship in the harbour, is the same young man at the end of Mayis Sikintisi (Clouds of May, 1999) who approaches the documentary filmmaker about the possibility of coming to Istanbul. And that idyllic rural community in Clouds of May is the same village Ceylan had sketched in misty, nostalgic, impressionistic images in Kasaba (The Small Town, 1997).

The Small Town, shot in black-and-white, is an impressionistic portrait of family life in an isolated village that's remarkable for its misty images, as though the entire film is the director's own nostalgic dream of times past. It was awarded the festival's Caligari Prize and receive a Special Mention in the Prix de Montreal competition for new directors at the 1998 Montreal World Film Festival. 
In Clouds of May Ceylan probes the psyche of a documentary filmmaker - again an autobiographical trait whose next production project takes him from Istanbul to the Anatolian village of his birth. The filmmaker's concern for the own project, however, prevents him from appreciating the rather obscure distress of his father, who needs his son to help validate his legal claim to a piece of land on which he has already built a house. As the title hints, Clouds of May leaves us with images reminiscent of Turner's landscape paintings: the peace of a idyllic wooded retreat and the languid beauty of a summer evening, to which are added the faces of people reflecting their deep roots in the rhythms and traditions of a rural community.

Distant picks up where Clouds of May left off. The rural cousin in Clouds of May who asks the filmmaker to help him find a job in the city is the same young man who comes knocking at the photographer's door in Distant. Mahmut (Muzaffer Özdemir), a photographer in his mid-forties and divorced, lives a quiet, unassuming, well-ordered existence in a tiny but tidy Istanbul flat. For all practical purposes, he has turned away from the outside world to nurture an inner life of calm with simple daily rituals, a self-imposed exile he has freely chosen (or so he thinks) to concentrate on his work and preoccupations. Each day, he goes to at the same bar at the same time to order the same beer. And when he feels the need for sex, a woman comes and departs without saying a word.

Into this closed world comes his cousin from the country: Yusuf (Mehmet Emin Toprak), in his midtwenties and unemployed after the factory in the area had closed down. Yusuf is hoping to find a job on the docks, then board a ship as a sailor "to see the world and get paid for it too." At first, Yusuf is impressed with Mahmut's style of living, although the house restrictions allows him to smoke only in the kitchen. But day after day during a dreary winter, with time on his hands and nothing really to talk about to a man who doesn't like to communicate anyway, Yusuf gives up the search for a job and a woman - and reluctantly decides to return home.

Yet this is only part of the story. The theme of Distant is found in its title: the slow passage of time, a space giving way to nothingness, a relationship that dies on the vine, a void that is never filled with anything meaningful, a life eventually felt (and experienced by the audience) for what it is: barren and colourless. Twice, given by Ceylan as a frame of aesthetic reference, we see Mahmut viewing a videotape of a Tarkovsky film. Nuri Bilge Ceylan is an auteur in the fullest sense of that jaded filmmaking term. He handles every phase of production: producer ("NBC Film" refers, or course, to the initials of his name), screenwriter, director, cameraman, set designer, co-editor. In Uzak the image is the whole film.

\section{A Prophecy Fulfilled: Denys Arcand's Les invasions barbares}

"I wrote this script over the last two years," said Denys Arcand in a statement about the making of Les invasions barbares (The Barbarian Invasions, Canada). "The subject had been haunting me for a long time, but I never seemed to find an approach that felt right to me. It always ended up in bleak, depressing scripts. One day, it dawned on me I should reunite the cast of wonderfully odd characters in Le déclin de l'empire américain (The Decline of the American Empire, 1987). Their sense of humour, their cynicism, and their wits would breathe in the lightness I was aspiring to. It so happened all the actors were ready and willing to embark on a new venture. Obviously, with the passing of time, the mood was now darker and the inevitable, closer. It was time to take stock."

The third double-award winner at Cannes - after Gus van Sant's Elephant and Nuri Bilge Ceylan's Distant - Denys Arcand's The Barbarian Invasions is the sequel to the director's Le déclin de l'empire américain (The Decline of the American Empire), a festival legend programmed 17 years ago at Cannes in the Directors Fortnight. If Arcand's The Decline of the American Empire has proved prophetic - and it has! - then his Barbarian Invasions scores as the best cinematic response to date to the "9/11" trauma. The same cast of wonderfully odd characters are back - all rebels in their own right, each with a hearty cynicism and a ribald wit to match. Denys Arcand was awarded Best Screenplay. Marie-Josée Croze as Nathalie, the young wayward daughter of one of the group who fights off a drug habit, was awarded Best Actress.

As the story goes, Gilles Jacob had his qualms about showing The Decline of the American Empire in the Competition at the 1986 Cannes festival. He waited until the last minute to reject it - whereupon 
Pierre-Henri Deleau booked it immediately to open the Directors Fortnight. It proved to be the sensation of the festival. Later, Jacob apologized personally to Arcand for the oversight, suggesting to him that the doors to the Sélection Officielle would be open for his next film. Arcand did, indeed, return three years later with Jesus de Montreal, awarded the Prix de Jury and the Ecumenical Prize at the 1989 Cannes festival.

Looking back, one cannot deny that The Decline of the American Empire has proven prophetic. It was, and remains, a harsh critique of the American "Way of Life" - hinting in assorted conversations among the protagonists, mostly intellectuals, that the social and cultural seams in (North) America had split asunder, and that another civilization crash like the one recounted in Gibbons's "The Fall of the Roman Empire" was imminent. Awarded the International Critics (FIPRESCI) Prize, it went on to become Canada's biggest success on the world film scene: an Academy Award Nomination for Best Foreign Language Film, nine Genie Awards (Canadian Oscars), the Quebec Film Critics Award, and several more international film awards.

Denys Arcand, born 1941 in Montreal, is one of the finest directorial talents to emerge from the National Film Board of Canada (NFB). Shortly after joining the NFB, he made Cotton Mill, Trademill (1970), a documentary about abuses in the Quebec textile industry. It was officially banned for six years because of its allegedly biased point of view. Equally controversial was his Quebec: Duplessis and After (1972), another politically-orientated documentary dealing with the political aftermath of Quebec ex-Prime Minister, Maurice Duplessis.

Leaving the NFB, Arcand directed his first fiction feature, Dirty Money (1972). A thriller about theft and murder with a pronounced ironic touch, it was invited to the International Week of the Critics at the 1972 Cannes festival. The next year, he was back in Cannes again with Rejeanne Padovanni (1973), selected by Directors' Fortnight and invited to the New York Film Festival. Other critical and commercial hits followed, among them The Crime of Ovide Plouffe (1974), which broke a box-office record in Quebec, and The Decline of the American Empire (1987), his breakthrough film. He was back in Cannes in 2000, closing the festival with Stardom, a satire on fame. All of Denys Arcand's films show his deep passion for history and characters from different social backgrounds.

In The Barbarian Invasions Rémy (Rémy Girard), divorced and in his early fifties, has been hospitalized with a serious illness. His ex-wife, Louise (Dorothée Berryman), asks their son Sébastien (Stéphane Rousseau) to return home from London to visit him. Sébastien hesitates; for he and his father never had much to say to each other, but he decides to fly to Montreal to help out his mother. As soon as he arrives, Sébastien reunites the "merry band" that had marked Rémy's past, and they gather around his father's bedside: relatives, friends, former mistresses. Among these is Nathalie (Marie-Josée Croze), the daughter of one of Rémy's former lovers, who plays a key role in the final deathbed scene.

What has become of these old rebels after an absence of nearly two decades? The old irreverences, the friendships spiced with belligerence, are still there. Humour, hedonism, desire still haunt their dreams. And their viewpoints on the American Way of Life, so much a part of the Canadian life style, are the same as that of Denys Arcand: "The American Empire is the world absolute ruler. As such, it will have to constantly push back the stream of barbarian attacks. 9/11 was the first that succeeded to strike at the Empire's heart, the first of many more to come ..."

\section{One Absurd Day: Raoul Ruiz's Ce jour-là}

"Is Raoul Ruiz a descendent of Breton, Aragon, Dali, Buñuel, Eluard? Yes, I sincerely think so," said French actress Elsa Zylberstein on the set of Ce jour-là (That Day), a French-Swiss coproduction marking the Chilean-born director's $10^{\text {th }}$ appearance at Cannes and the fifth time in the Sélection Officielle. "He has a gift to mix everything up: a joie de vivre, an originality, a lunacy, an irony, an immense lucidity." Paulo Branco, an admiring support of the director, is producing again. And Raoul's wife, Valéria Sarmiento, a filmmaker in her own right, has edited the film.

Raoul (Raúl is the Spanish spelling) Ruiz is a regular at Cannes. Last year, he served on the Inter- 
national Jury. Two years ago, he closed the 2001 Cannes festival with Les ames fortes (Savage Souls), the story of a wild young girl from the provinces who runs away from her conniving boyfriend - John Malkovich in one of his better roles for foreign directors - to take refuge at the manor of a rich woman just as savage in her own way as she is. And, in 1999, Ruiz stopped traffic on the Croisette when his Marcel Proust adaptation, Le temps retrouvé (Time Regained), starring Catherine Deneuve as the demi-mondaine Odette de Crécy and John Malkovich as the loony Baron de Carlus, was programmed on a Sunday afternoon during a holiday weekend.

As for his two other competition entries at Cannes, Ruiz's Trois vies et une seule mort (Three Lives and Only One Death, 1996), a French-Chilean coproduction, is a weird tale of entangled stories that keep crossing paths in what the director declares is an attempt at structural cubism in cinema. And his L'oeil qui ment (Dark Noon, 1992), another French-Chilean coproduction, is an avant-garde tale set in Paris at the end of the First World War that stars John Hurt as a doctor-researcher who specializes in unexplained medical recoveries bordering on miracles.

Born in 1941 in Puerto Montt, Chile, as the son of a ship's captain, Raúl Ruiz studied law and theology at the University of Chile, learned the fundamentals of filmmaking in Argentina, penned a series of stage plays for avant-garde theatres in Santiago, and worked as both writer and technician for TV stations in Chile and Mexico. With money borrowed from family and friends, he directed his first feature film, Tres tristes tigres (Three Sad Tigers, 1968), a subtle exposé of the Chilean middle-class, and was awarded the Golden Leopard at Locarno. Six years later, following the Allende coup in 1973, he arrived in Paris as a political exile with a print of La expropriacion (Expropriation, 1974) under his arm - and was immediately invited by Pierre-Henri Deleau to show the film at the 1974 Directors Fortnight at Cannes.

A prolific filmmaker, Raoul Ruiz has directed in the neighbourhood of 75 films over the past 30 years. And like Luis Buñuel before him, he feels at home in just about any genre - provided he is allowed by his producer to add an ironic or absurd or humorous twist to an otherwise bold narrative line. His innovative use of decor, lighting, and camera techniques have earned him the favour of the French and European avant-garde. Also, his intellectual esprit and playful approach to cinema have gained the respect of well known screen personalities, actors who enjoy working for and will go out of the way to collaborate on a project with him. Catherine Deneuve starred in his Dostoevsky-like spoof of Freudian psychoanalysis, Généologies d'un crime (Genealogy of a Crime, 1996), awarded a Silver Bear at the 1997 Berlinale. William Baldwin appeared in Shattered Image (1998), and Isabelle Huppert could be seen in Comedy of Innocence (2000).

Ruiz's French productions were programmed regularly at Cannes in the Perspectives of French Cinema section: The Hypothesis of the Stolen Painting (1978), Manuel's Destinies (1985), and Richard III (1986). Then came another breakthrough of sorts at Cannes when his L'̂̀le au trésor (Treasure Island, 1991) was invited to Un Certain Regard in 1991. Treasure Island, the story of a perverse children's game of chance and guessing that pushes adult participants to their rational limits, was the forerunner of Combat d'amour en songe (Chilean Rhapsody, 2000), a Chilean-Portuguese-French coproduction. A make-believe fairy tale about a treasure hunt starring Elsa Zylberstein and Lambert Wilson, Chilean Rhapsody was invited to compete at the Montreal World Film Festival and was awarded there the FIPRESCI Prize.

Elsa Zylberstein and Raoul Ruiz collaborated again on Ce jour-là, a French-Swiss coproduction. She plays young, beautiful Livia, the sole heiress of an immense fortune, who lives alone on a large Swiss estate and is envied by the rest of the family. The spiteful sycophants hire Emil (Bernard Giraudeau), a diabetic contract killer just released from an asylum, to stalk and kill her. But once Emil and Livia meet on "that day," they become good friends. The wheel of fortune turns - and the plotters become the victims.

\section{Resistance in Shanghai: Ye Lou's Purple Butterfly}

"This is a story that took place in Shanghai more than 70 years ago, in the early 1930s of the last century," said YE Lou (Lou Ye) in a director's statement about Purple Butterfly (China). "But when you try to return to those days - to make a movie or tell a story - you quickly discover that nothing much has changed. 
The people in that period faced more or less the problems we face today. Our lives are still chaotic, still hard to grasp or control."

Shanghai, once the "Pearl of the Orient," was a turbulent city during the 1930s - literally the crossroads of the world. Hundreds of Germans fleeing Hitler's suppression of Jews and intellectuals landed here, simply because they didn't need a visa to get into this open seaport city. It was a centre for the opium trade. The "International Settlement" was noted for its banks and hotels, its gambling clubs and houses of pleasure. The enclaves were havens of British and western cultural life. Old Chinese customs clashed with alien modern dress and ways. Artists and entrepreneurs, thieves and conmen, adventurers and fortune-seekers, carefree globetrotters and exiled monarchs rubbed shoulders with each other. They came and went or stayed. Some stayed too long - and found themselves stranded. It was the last stop for tired wealthy travellers and desperate refugees from Europe. Japanese businessmen and diplomats waited for their moment of destiny: the Japanese invasion was about to begin.

As a frame of reference, try Vicki Baum's novel, Hotel Shanghai, brought to the screen by the late Berlin producer Manfred Durniok. Set in 1937 in the majestic Cathay Hotel, it takes the pulse of a time when the ebb and flow of diplomatic intrigue and complex human relationships had reached its high point. Ten years in the making and completed in 1996, Hotel Shanghai was at that time the most costly Chinese production on record with a European producer. Directed by Peter Patzak and shot on actual Shanghai locations, with an international cast and 4,000 Chinese extras, it cost an estimated $\$ 8.5$ million. The Chinese art director was the celebrated Qin Baison, who had collaborated with Zhang Yimou on his award-winning Chinese epics.

Purple Butterfly opens in 1928 in Shanghai. Itami (Toru Nakamura), a young Japanese, falls in love with Cynthia (Zhang Ziyi), a Chinese girl, who later changes her name to Ding Hui. Their brief tryst ends when Itami is called home for his military service. Upon returning home from the train station, she witnesses the murder of her brother by Japanese right-wing extremists. Three years later, with Shanghai "unofficially" occupied by the Japanese through acts of terror and violence, the city is tense and about to explode. Ding Hui has joined the "Purple Butterfly," a Chinese resistance group planning to assassinate Yamamoto, the head of the Japanese secret service. Itami is also back in Shanghai, operating as a secret agent reporting directly to Yamamoto. When Szeto (Liu Ye), a young Chinese, is mistaken for the hired Yamamoto assassin, a gunfight erupts in the Shanghai Station - and Szeto's fiancée is accidentally killed. Szeto now joins the Purple Butterfly too. The fates of three young people - Ding Hui, Szeto, Itami - are interlinked and predestined to tragedy.

Born 1965 in Shanghai, Lou Ye graduated in 1989 from the Beijing Film Academy. After making several short films, he directed the feature Weekend Lover (1993), awarded the Rainer Werner Fassbinder Prize for Best Director at the Mannheim-Heidelberg film festival. His second feature, Suzhou River (1998), a metaphorical statement remarkable for its broken time frames, was shot illegally in Shanghai without receiving script approval from the authorities. Further, Ye had also coproduced the film. Suzhou River received the Tiger Award at the 2000 Rotterdam film festival. A director with style and vision, Ye's talent is on full display in Purple Butterfly, an epic tale of doomed passions, mistaken identities, political intrigue, with a narrative line along the lines of a Leone western.

\section{Spiritual Elegy: Alexander Sokurov's Father and Son}

Most Russian critics had nothing but praise for Alexander Sokurov's cycle of short poetic "elegies" on people and places in Russia and the ex-Soviet Union. Altogether, they number seven to date: Elegy (1985), Moscow Elegy (1987/88), Soviet Elegy (1989), St. Petersburg Elegy (1989), Simple Elegy (1990), Russian Elegy (1992), and Oriental Elegy (1996). Sokurov's first feature-length "spiritual elegy was Mat I syn (Mother and Son, 1997), a poetic film that breathed the same spirituality as found in the previous elegies. And it is an elegy in the truest sense. Indeed, Mother and Son is a haunting, poignant sketch of a son's undying love for his mother, as he carries her to a resting place before she breathes her last breath. Shown at the International Forum of Young Cinema at the 1998 Berlinale, it also confirmed Sokurov as one of Russia's leading filmmakers.

Moreover, Mother and Son provided the appropriate stylistic design and striking visual imagery for 
Moloch (1999), Sokurov's first Cannes entry. A contentious Russian-German coproduction about a day in the life of Eva Braun, originally titled The Mystery of the Mountain, Moloch is about a day in the lives of Eva and Adolf atop the Führer's Alpine retreat in Berchtesgaden in the late spring of 1942, a couple of months before the German defeat at Stalingrad. In this film Sokurov approached his subjects from a dream-like distance by filtering the images through a brownish gauze or optic veil. Taurus (2000), his second Cannes entry, again challenged critics and historians with a controversial account of Lenin's Last Days, the film's other given title. Again, Sokurov filmed the action through a green-greyish filter to emphasize the fictionally exaggerated, almost nightmarish, dimension of the theme. Russian Ark (2002), his third Cannes entry, was a one-shot, HD Steadicam, digital-25p masterpiece that falls a bit out of the pale of the director's stylistic vision. Filmed in the 35 rooms of the Hermitage and the Winter Palace at St. Petersburg, it embraced 400 years of Russian history and cultural life. This exercise in digital shooting also prepared the way for the concept and shooting of Otets I syn (Father and Son), Sokurov's fourth Cannes entry in five years.

As the title hints, Father and Son is the natural analogue to Mother and Son, a spiritual elegy mourning again the death of a woman and mother - in this case, the father's dead wife as seen, and revisited in a dream sequence, in the persona of the son. As usual in a Sokurov film, the approach is hermetic and, one might say in this instance, homoerotic. But Father and Son is anything but a homosexual statement, nor is it the director's "coming-out" film. Rather, the attraction of the father for the presence of the son, spiritually as well as physically, is filtered through illuminating sepia-tone hues as though the entire film was shot in blazing sunshine. Set mostly atop connecting roofs in the city of Lisbon, with glimpses of the sea in the distance, these scenes are augmented in turn by the father's past as an army general and the son's stay in a military academy. That Father and Son is a spiritual elegy anchored to Russian Orthodox belief is attested by repeated sentences spoken to each other by the pair: "A son who loves his father will sacrifice himself for him. A father who loves his son will crucify him." Father and Son, the second film in a planned trilogy, was awarded the International Critics (FIPRESCI) Prize at Cannes.

It's worth noting, too, that all of Sokurov's Cannes entries have been co-financed by German producers, a happenstance that has raised eyebrows on more than one occasion. Before Moloch - originally titled The Mystery of the Mountain before its Cannes screening - some critics shook their heads over the very boldness of the project. For a film about Eva Braun and Adolf Hitler directed by a Russian with Russian actors speaking dubbed German sounded rather implausible, to say the least. But Alexander Sokurov is not an ordinary Russian director. Among his 30 plus credits as a director is a 10-minute montage-documentary titled Sonata for Hitler (1979), made 20 years ago. On the making of Moloch he offered these comments: "These people, the people of power, turned their lives into theatre. Guided by a myth, they conceived and modified their lives, staged real mise en scène and subordinated their behaviour to rituals and ceremonies. This pattern is by no means unique, and Hitler was not exceptional. It's a common occurrence that grandiose shows driven by vanity end up in the dustbin of history."

The "dustbin of history" aptly describes Lenin's last days in Taurus as well. Sokurov depicts the great leader at his estate as a tired, restless old man out of sync with history and the revolution forces he had once set in motion. Crippled by a stroke, he feels himself over-protected by his wife and women relatives as he waits in vain for an "important phone call" from the Central Committee in Moscow. Finally, an eery Josef Stalin appears on the scene - he's there to check out Lenin's health, not to confer with his mentor and on the state of world events. That one scene says more about the myths of contemporary Russian history than a score of enlightening books on the subject. No wonder some leftist critics were up in arms at Cannes!

Of the three Russian stylists once named as "rightful heirs" to the art cinema of Andrei Tarkovsky Ivan Dykhovichny, the late Alexander Kaidanovsky, and Alexander Sokurov - only Sokurov's cinema has survived the test of time. Always searching for new ways to employ the language of cinema, he probes the human experience through the eyes of a sceptic and pessimist. One meeting with Alexander Sokurov is all that's needed to feel that down deep he's a restless man, a filmmaker who invites controversy by the very choice of his themes, an artist who will talk circles around the meaning of his films rather than offer any kind of direct answers that may come back later to haunt him. Add to this the disturbing news that he is gradually losing his eyesight, and respect and admiration for his visual style of "filming through a veil" can 
hardly be denied.

Born in Siberia into a military family that was always on the move, this background helps to fathom some of the hidden associations in Father and Son. Sokurov spent his childhood in Poland, his youth in Turkistan, and his university years in Gorky and Moscow before settling down in St. Petersburg to work at the Lenfilm Studios on documentaries and feature films. When his diploma film at the Moscow Film School (VGIK), The Lonely Voice of Man (1978), was rejected by school officials as being too negative and pessimistic, Andrei Tarkovsky was among those who spoke out in his defence. Moving on to Leningrad (today St. Petersburg) to make Lenfilm his permanent base, Alexander Sokurov spent most of the 1980s fighting to get his films released, if not completely banned with the negatives destroyed. In the case of The Summer of Maria Voynova, aka Mariya (1978-88), he had to wait a decade for this portrait of an exploited woman labourer on a collective farm to be released in its uncut version. His literary homage to George Bernard Shaw, Painful Indifference (1983-87), had to be pieced together from a partially destroyed negative when it was presented at the Berlinale.

\section{Makhmalbaf Film House: Samira Makhmalbaf's At Five in the Afternoon}

Email the Makhmalbaf Film House in Tehran, mailto:\%5Bmakhmalbaf.film@tavana.net and you'll usually get back the latest bunch of interviews, critiques, filmographies about all the key members of this remarkable family. Once, I even downloaded a 50-page treatise on why Mohsen Makhmalbaf had risked his life to shoot Kandahar, his 2001 Cannes festival entry, in the camps of starving Afghani refugees just over the Iranian border. That year, there was also the occasion of the Samira Makhmalbaf photo exhibition at Cannes. And, by the way, Samira served on the Short Film and Cinéfondation Jury at the 2001 Cannes festival.

Keeping up with the Makhmalbaf film-family tree - father Mohsen Makhmalbaf, mother Merziyeh Meshkini, daughter Samira, son Maysam, and another daughter Hana - has become a must for critics, festival directors, and cineastes deep into Iranian and Far East cinema. Their regular presence at key international film festivals - Cannes, Venice, Berlin, Locarno - was capped at the 2000 Pusan International Film Festival with a "Salaam Cinema! Films of the Makhmalbaf Family" retrospective, where it caught the eye of Kiril Masgalov, artistic director of the Moscow festival, who promptly booked it for his own 2001 event. In addition to the dozen films in the Moscow tribute, there was time set aside for an in-depth "conversation" with Mohsen Makhmalbaf on his literary output: novels, short stories, journalist tracts, theses on Islamic art and theatre, and more. But the tribute hit a snag, when the Russian government apparently failed to issue the necessary visas in time for the entire Makhmalbaf family.

With some 25 shorts, documentaries, and features to his name, Mohsen Makhmalbaf is recognized at home and abroad as an authentic film revolutionary. Born 1957 in Tehran, he was thrown into prison at 17 for five years for resisting the Shah regime. Set free after the revolution, he published a novel, several short stories, and directed his first film, Nosuh's Repentance (1982). With the success of his neorealist The Pedlar (1987) and The Cyclist (1988), the latter about an Afghani refugee in Iran and the forerunner of Kandahar, Makhmalbaf found himself increasingly in conflict with Islamic authorities. His Time of Love (1990), programmed in Un Certain Regard at Cannes, was banned for "deviant religious views" at home.

Thereafter, Mohsen Makhmalbaf became a regular at Cannes: Salaam Cinema (1995), Gabbeh (1996), The Door episode in Kish Tales (1999), and Kandahar (2001). But he also premiered A Moment of Innocence (1996) at Locarno and competed at Venice with The Silence (1998). In addition, he wrote the scripts for Samira Makhmalbaf's The Apple (1998), the debut feature of his 18-year-old daughter selected for Un Certain Regard at Cannes, followed by Blackboards (2000), awarded the Prix de Jury at Cannes. And he wrote the script for Merziyeh Meshkini's The Day I Became a Woman (2000), his wife's awarded Venice entry. The best illustration on how the family members are interlinked on mutual productions can be found in Maysam Makhmalbaf's How Samira Made Blackboards (2000), a brother's view of why his sister left school to work as an assistant for their father and learn firsthand the art of cinema and the craft of filmmaking.

At 18, Samira Makhmalbaf is the youngest director ever to present a feature film in the Sélection Officielle at Cannes. Moreover, The Apple, her Certain Regard entry at the 1998 Cannes festival, was 
not only scripted but edited by her father, Mohsen Makhmalbaf. Indeed, Samira has followed in the sure footsteps of her father to Cannes. Remember Mohsen Makhmalbaf's Time of Love (1991)? It had eventually to be cleared by the Iranian censors for a Certain Regard screening at the 1995 Cannes festival. And his Salaam, Cinema, a docu-drama invited to Cannes for the 1998 "Centennial of Cinema" celebration - not by coincidence, the same year as his daughter's The Apple - mirrored the consuming desire of many Iranian women to be in films. And like her father, Samira Makhmalbaf approaches filmmaking as a moral medium, one of search and reflection, one in which the director's primary focus should be on human dignity - and, if necessary, on the dark side of human behaviour. As a seven-year-old, she had her own first experience before the camera: acting in Mohsen Makhmalbaf's The Cyclist (1989). At 16, she took her first courses in filmmaking, later shot two shorts, and still found time to assist her father on the set.

In The Apple, the original point of departure was an ordinary street in a poor district of Tehran. Several families had written to the Social Services Office about a father who had locked up his two young daughters since birth. When a social worker called on the family, the father responded: "My daughters are like flowers - expose them to the sun, and they will wither away!" The moral quest for answers prodded Samira Makhmalbaf to go further: "I wanted to discover who had forced the parents, despite their love, to lock up their own children. And I wanted to know why some neighbours chose to ignore the affair, and even remain indifferent, for such a long time ..."

In Pan é asr (At Five in the Afternoon), Samira Makhmalbaf picks up where her father had left off in Safar e Gandehar (The Road to Kandahar). Both are Iranian-French coproductions. A Competition entry at the 2001 Cannes festival, Mohsen Makhmalbaf's The Road to Kandahar, photographed by talented Iranian cameraman Ebrahim Ghafori, was promoted in advance via the homepage of the Makhmalbaf Film House with well researched documentation on why "The Buddha Was Not Demolished in Afghanistan - It Collapsed Out of Shame." In other words, Mohsen Makhmalbaf wanted to make sure the viewer didn't miss the point when he went to see Kandahar. For although Kandahar was researched in the refugee camps of neighbouring countries near the Afghani borders, some of the footage was apparently shot at refugee sites within Afghanistan as well.

Kandahar evoked sympathy for the plight of Afghani refugees living abroad. When Nafas, a young Afghani journalist who had taken refuge in Canada during the time of the civil war with the Taleban, receives a desperate letter from her younger sister in Afghanistan, she hurries back to Kandahar to save her sister from committing suicide. She tries to enter Afghanistan by the way she had previously exited the country - via the Niatak refugee camp at the Iran-Afghanistan border. It's here that the film really begins - and ends.

In Samira Makhmalbaf's At Five in the Afternoon, also photographed by Ebrahim Ghafori, Afghani refugees have crossed the borders from Iran and Pakistan to return to the former homes in post-Taliban Afghanistan. Among these is a young woman, Nogreh (Agheleh Rezaïe), who returns to Kabul accompanied by her father and mother. Sent to a religious school in her blue burqa, Nogreh slips away "at five in the afternoon" to discard her head-covering and don a pair of high-heeled shoes. She wants to hear the music long forbidden by Taleban rules. And she wants to breathe the fresh air of a liberated society. When she meets a poet in the streets, she proclaims her secret desire to become the "president of the country." Meanwhile, her father, steeped in religious ways and traditions, is horrified at the "blasphemy" he encounters in Kabul - particularly the appearance of unveiled women in the streets. Finally, he can stand no more. Together with his family, which now includes the sick baby of his step-daughter, he flees into the desert. At Five in the Afternoon was awarded the Prix de Jury and the Ecumenical Prize.

But the story of the Makhmalbaf Film House doesn't end there. While Iranian cameraman Ebrahim Ghafori was working with Samira Makhmalbaf on At Five in the Afternoon in Afghanistan, he met Afghani director Sedigh Barmak, who asked him to shoot Osama, the first Afghani feature film made in the country since the war. Due largely to his collaborative support, Osama received a Special Mention by the Caméra d'Or Jury. 


\section{References}

AWARDS

OFFICIAL COMPETITION

Palme dOr: Elephant (USA), Gus van Sant

Grand Prix: Uzak (Distant, Turkey), Nuri Bilge Ceylan

Best Director: Gus van Sant, Elephant (USA)

Best Screenplay: Denys Arcand, Les invasions barbares (The Barbarian Invasions, Canada)

Best Actress: Marie-Josée Croze in Les invasions barbares (The Barbarian Invasions, Canada), Denys Arcand

Best Actor: (ex aequo) Mehmet Emin Toprak (post mortem) and Muzaffer Özdemir in Uzak (Distant, Turkey), Nuri Bilge Ceylan

Jury Prize: Pan é asr (At Five in the Afternoon, Iran-France), Samira Makhmalbaf

Short Film Awards

Palme d'Or: Cracker Bag, (Australia), Glendyn Ivin

Jury Prize: L'homme sans tête (The Man without a Head, France), Juan Solanas

Caméra d'Or (Best Debut Feature): Reconstruction (Denmark), Christoffer Boe (International Critics Week)

Special Mention: Osama (Afghanistan-Japan-Ireland), Sedigh Barmak (Directors Fortnight)

Cinéfondation Awards

First Prize: Bezi, zeko, bezi (Run, Rabbit, Run, Serbia), Pavle Vucovic

Second Prize: Historia del desierto (Story of the Desert, Spain), Celia Galán Julve

Third Prize: (ex aequo) Rebecca a esas alturas (At That Point ...Rebecca, Mexico), Luciana Jauffred Gorostiza, and TV City (Argentina), Alberto Couceiro, Alejandra Tomei

International Critics (FIPRESCI) Awards

Competition: Otets I syn (Father and Son, Russia-Germany), Alexander Sokurov

Un Certain Regard: American Splendor (USA), Shari Sprinter Barman, Robert Pulcini

Quinzaine des Réalisateurs: Las horas del dia (The Hours of the Day, Spain), Jaime Rosales

Ecumenical Award: Pan é asr (At Five in the Afternoon, Iran-France), Samira Makhmalbaf

Le Prix Un Certain Regard

Un Certain Regard: La meglio gioventù (title of old song, Italy), Marco Tulio Giordana

Le Premier Regard: Mille mois (A Thousand Months, Morocco), Faouzi Bensaidi

Prix de Jury: Talaye sorgh (Crimson Gold, Iran), Jafar Panahi

Semaine Internationale de la Critique

Grand Prix: Depuis qu'Otar est parti (Since Otar Left, France-Belgium), Julie Bertucelli

Prix Canal+ (Best Short Film): Love Is the Law (Norway), Eivind Tolas

Prix Kodak (Short Film): The Truth about Head (Canada), Dale Heslip

Prix de la Jeune Critique

Feature Film: Milwaukee, Minnesota (USA), Allan Mindel 
Short Film: (ex aequo) The Truth about Head (Canada), Dale Heslip, and Love Is the Law (Norway), Eivind Tolas

Grand Rail d'Or: Milwaukee, Minnesota (USA), Allan Mindel

Petit Rail d'Or: Depuis qu'Otar est parti (Since Otar Left, France-Belgium), Julie Bertucelli

Label Regards Jeunes

Feature Film: Reconstruction (Denmark), Christoffer Boe

Short Film: The Truth about Head (Canada), Dale Heslip

\section{Author Information}

Ron HOLLOWAY (1933-2009) was an American critic, film historian, filmmaker and correspondent who adopted Europe as his home in the early fifties and spent much of his life in Berlin. He was an expert on the study of German cinema and against all odds produced, with his wife Dorothea, the journal German Film, keeping us up-to-date with the work of directors, producers and writers and the showing of German films around the world.

In 2007, Ron Holloway and his wife were awarded the Berlinale Camera Award. Ron also received the Bundesverdienstkreuz (German Cross of Merit), Polish Rings, Cannes Gold Medaille, the American Cinema Foundation Award, the Diploma for Support of Russian Cinema and an honorary award from the German Film Critics' Association.

Ron was also a valued contributor to Kinema for the past fifteen years. 